\title{
INNOVATION AND NEW ROLES OF EMPLOYEES IN OPERATIONAL RISK MANAGEMENT
}

\author{
Marija Antonijević, \\ Isidora Ljumović \\ Institute of Economic Sciences, \\ Belgrade, Serbia
}

\begin{abstract}
:
Innovations have become an everyday part of modern business, which has not bypassed the financial sector. Survival on the market depends on the way banks adapt to new circumstances and trends, such as introduction of new products, services, processes or organizational forms. The report of the Basel Committee on Banking Supervision for 2019 points out that financial technologies and innovations increase the complexity of providing financial services, as well as the level of operational risk, making it more difficult to manage and control it.

Considering the above, the aim of this paper is to try to determine the impact of the introduction of innovations on the level of operational risk, especially focusing on the human factor and employment. The results for the period 2011-2019, including 26 banks, show that there was an increase in the capital requirements for operational risk and a downsize in the number of employees. However, we could not find strong evidence that this happened due to the introduction of innovative product and services in the banking sector of Serbia.
\end{abstract}

Keywords:

banking sector, innovations, operational risk, bank employees.

\section{INTRODUCTION}

Banks and other financial intermediaries are in the service business, where clients constantly expect faster, more precise and accurate services that are tailored to their needs. Although financial innovations are not a new concept, current focus is on the technological innovations, that have significantly increased application in the sector of banking and finance. Rapid and intense changes and innovations are altering the world including the banking sector, bringing technological progress and social changes, both for client and employees. Banks are one of the major users of new information and communication technologies with two main goals - to cut the costs and increase the profit and to alter channels of distribution making them more efficient and convenient. Basically, banks use innovation to obtain or increase competitive advantage, improve financial and economic situation, or adjust to changing conditions (Kopernik, 2019).

In order for banks to respond to changes in the environment, it is necessary to adapt and offer customers services with a better experience that are in line with current technologies. Bank customers understand this change, but it is also perceived by the bank employees. According to the KPMG research conducted on the sample of 130 young bank employees, $75 \%$ of them expect that banks will be technology driven companies (KPMG, 2015).

There are serious indications that the introduction of new technologies and innovations in banking will significantly affect the structure and number of employees in banks around the world. 
Based on Wells Fargo estimates, investment in new technology could lead to layoffs of 200,000 employees in the next decade. Also, as a consequence of the introduction of new technologies and innovation in the banking sector, a large number of branches were closed because clients prefer to communicate and perform virtual transactions with the bank. The results of the research conducted by EY on 1,250 banks in 2019 indicate that the transition to digital strategies and operational risk are identified as major threats, namely in the third and sixth place, respectively (EY, 2020). As a consequence of innovative technologies, bank employees have new roles and need additional knowledge and skills. The EY 2016 report suggests that the banking sector needs fresh talent and is in search for new employees which are characterized by latest skills in all business activities (EY, 2016). The KPMG survey conducted on 132 banking CEOs in 2019 showed that $65 \%$ of respondents stated that they need to upgrade innovation process (KPMG, 2020). The internet banking had an impact on reducing the number of employees in the Netherlands, especially at mid-level jobs. About 40,000 people have been laid off in the three largest Dutch banks, which also indicate future layoffs in the sector (Neufeind et. al., 2018: 309).

The aim of this paper is to determine how the increase in operational risk, which, among others, arises due to the introduction of innovation in the banking sector, affects the roles of employees. For this purpose, we analysed available data for 26 banks operating on the territory of the Republic of Serbia. According to the analysis the number of innovations in the banking sector is rapidly increasing, together with the level of operational risk. On the other hand, there is a constant decrease in the number of employees in the banking sector of the Republic of Serbia. Increased risks and new products put additional pressure for the employees and are implying for a need to invest in employees training.

\section{INNOVATION AND OPERATIONAL RISK}

Frame and White are among the first authors who paid considerable attention to the concept of financial innovations. They include new products, new services, new processes or new organizational forms, which they develop in cooperation with software companies and act as the final user of innovations (Frame \& White, 2004: $118,123)$. According to the Oslo manual, financial innovations are defined as a set of new or significantly improved solutions employed by the banking sector in all innovation areas: product, process, organisation, and marketing (OECD, 2005: 48-55). The list of innovation in commercial banking is changing quite rapidly, and while e-banking, m-banking, ATM and other have changed the face of banking, new technology-driven innovation in financial services, or "fintech" caused fewer branches and bank employees, larger IT budgets, longer opening hours, and shorter transaction times (BIS, 2018). The report of the Basel Committee for Banking Supervision for 2019 points to higher operational risk arising from financial technologies and innovations that increase the complexity of providing financial services, making it more difficult to manage and control operational risk (Basel Committee on Banking Supervision, 2018). A survey conducted by EY in 2017 on a sample of 221 banks, covering 29 markets, showed that in the coming period, the priority for $85 \%$ of bank executives is the implementation of digital transformation programs, while $81 \%$ of them believe that the priority is to invest in technology (EY, 2018).

In order to analyse the level of innovation among Serbian banks, we have developed an indicator related to the number of innovative products and services banks offer to their clients. As relevant according to Ekpu we have identified following innovative services: e-banking, $\mathrm{m}$ banking, chatbot, online credit, multifunctional ATMs and smartphone as wallet (Ekpu, 2015). Although innovations such as e-banking and $\mathrm{m}$-banking belong to the first wave, they are included in the analysis in this paper, because a larger offer of these services and mass use began several years ago. The data related to products and services offered by banks to clients were obtained on the basis of information from the banks' website, as well as by sending inquiries by e-mail and talking to operators. The analysis includes 26 banks operating in the territory of the Republic of Serbia in the last three years, since we could not obtain data for previous years. The importance of innovation is reflected in the fact that the number of payment service users has increased. The number of ebanking users in the second quarter of 2020 compared to the end of 2016 increased by $80 \%$, i.e. to $2,933,227$. On the other hand, the number of users of payment services using mobile banking has increased by 2.5 times i.e. to $1,921,347$ (National bank of Serbia, Statistic, https://nbs.rs/sr_RS/ drugi-nivo-navigacije/statistika/). The products and services offered by banks in 2019 are presented below. While e-banking and $\mathrm{m}$-banking are currently standard services for most of the banks operating in Serbia, other analysed innovations are still sporadic. Largest banks according to the market share, have introduced the largest number of innovations, which indicates their dominant role in the introduction of innovations (Table 1). 
Table 1. Types of innovative products and services banks were offering in Serbia in 2019:

\begin{tabular}{|c|c|c|c|c|c|c|}
\hline Bank & E-banking & M-banking & Chatbot & Online loan & $\begin{array}{l}\text { Multifunctional } \\
\text { ATM }\end{array}$ & $\begin{array}{c}\text { Smartphone as } \\
\text { wallet }\end{array}$ \\
\hline Addiko & $\checkmark$ & $\checkmark$ & $\checkmark$ & $\checkmark$ & & \\
\hline AIK & $\checkmark$ & $\checkmark$ & & & $\checkmark$ & $\checkmark$ \\
\hline Alta & $\checkmark$ & $\checkmark$ & & & & \\
\hline API & $\checkmark$ & $\checkmark$ & & & & \\
\hline Banca Intesa & $\checkmark$ & $\checkmark$ & & $\checkmark$ & $\checkmark$ & $\checkmark$ \\
\hline Bank of China & $\checkmark$ & & & & & \\
\hline Credit Agricole & $\checkmark$ & $\checkmark$ & & & & \\
\hline Direktna & $\checkmark$ & $\checkmark$ & & & & \\
\hline Erste Bank & $\checkmark$ & $\checkmark$ & & $\checkmark$ & & \\
\hline Eurobank & $\checkmark$ & $\checkmark$ & & $\checkmark$ & $\checkmark$ & \\
\hline Expobank & $\checkmark$ & & & & & \\
\hline Halkbank & $\checkmark$ & $\checkmark$ & & & & \\
\hline Komercijalna & $\checkmark$ & $\checkmark$ & $\checkmark$ & $\checkmark$ & $\checkmark$ & $\checkmark$ \\
\hline Mirabank & $\checkmark$ & $\checkmark$ & & & & \\
\hline Mobi & $\checkmark$ & $\checkmark$ & & $\checkmark$ & $\checkmark$ & \\
\hline MTS & $\checkmark$ & $\checkmark$ & & & & \\
\hline NLB & $\checkmark$ & $\checkmark$ & & $\checkmark$ & & \\
\hline Opportunity & $\checkmark$ & & & & & \\
\hline OTP & $\checkmark$ & $\checkmark$ & & & & $\checkmark$ \\
\hline $\begin{array}{l}\text { Poštanska } \\
\text { Štedionica }\end{array}$ & $\checkmark$ & $\checkmark$ & & & & \\
\hline ProCredit & $\checkmark$ & $\checkmark$ & & & $\checkmark$ & \\
\hline Raiffeisen & $\checkmark$ & $\checkmark$ & $\checkmark$ & $\checkmark$ & $\checkmark$ & $\checkmark$ \\
\hline Sberbank & $\checkmark$ & $\checkmark$ & & $\checkmark$ & $\checkmark$ & \\
\hline Srpska & $\checkmark$ & & & & & \\
\hline UniCredit & $\checkmark$ & $\checkmark$ & & & $\checkmark$ & \\
\hline Vojvođanska & $\checkmark$ & $\checkmark$ & & & $\checkmark$ & \\
\hline
\end{tabular}

Source: Author's calculation

As can be seen from the Table 2, in the last 3 years the number of total innovations in the banking sector has been growing, which indicates that banks are trying to adapt to the market demand and offer clients digital products and services. Transactions previously performed by customers in the bank are now replaced by new and more innovative solutions. This implies that banks are responding to the new demands of their customers and society, with almost a radical transformation. Competition among banks worldwide is high, as evidenced by the global consolidation of the banking sectors and the decrease in the number of banks worldwide. New ways to increase efficiency and profitability and reduce costs are constantly being sought. The introduction of innovation is one of the ways to achieve these goals. In this regard, a significant number of banks have opted to develop innovative concepts and use new products and services to increase market share in a rapidly changing marketplace. 
Table 2. Adoption of innovation by Serbian banks during the period $2017-2019$

\begin{tabular}{lccc}
\hline & Number of banks & 2018 & 2019 \\
\hline Type of innovation & 2017 & 26 & 26 \\
\hline E-banking & 26 & 22 & 22 \\
\hline M-banking & 21 & 3 & 3 \\
\hline Chatbot & 1 & 4 & 9 \\
\hline Online loan & 1 & 6 & 10 \\
\hline Multifunctional ATM & 5 & 4 & 5 \\
\hline Smartphone as wallet & 3 & 65 & 75 \\
\hline Total & 57 & & 2 \\
\hline
\end{tabular}

Source: Author's calculation

According to Basel Accords (2004) operational risk is defined as the risk of loss arising from inadequate or erroneous internal processes, people and systems or from external events. Based on this definition it is obvious that human factors, manifested as the behaviour of employees, clients and their mutual interaction have a direct impact on operational risk. The Basel definition includes legal risk; however, it excludes strategic and reputational risk (Đukić, 2016: 45). In the Republic of Serbia operational risk is defined according to the Decision on Risk Management by Banks as the risk of possible negative effects on the financial result and capital of the bank due to omissions (unintentional and intentional) in the work of employees, inadequate internal procedures and processes, inadequate management of information and other systems in the bank, as well as due to the unforeseen external events, which include legal risk (Decision on Risk Management by Banks RS Official Gazette, 2011: 40).

The bank is exposed to operational risks due to inadequate functioning of the information system, reporting system of internal rules for risk monitoring, as well as inappropriate internal procedures and their non-compliance with internal rules. One of the cases that contribute loss is the human factor. Operational risk includes human factor risks related to the insufficient culture of behaviour in relation to exposure to operational risks, insufficient number of employees, management risk, internal criminal activities, etc. Namely, due to insufficient experience, noncompliance with procedures, policies and the code of ethics, errors in work occur (Đukić, 2016: 45). In the world where bank innovations are introduced rapidly, and the level of operational risk is rising, the chance of exposing the bank to operational risk by employees is rising, usually as a consequence of inadequate training of employees or their overtime and hard work. If an employee has a heavier workload on any given day, then the total number of errors on that day increases convexly (Xu et. al., 2017).
The results of a survey conducted by Massachusetts management consulting services firm Bain \& Company on a sample of 96 banks in the period 2011-2016 showed that about 8 billion, i.e. about $4 \%$ of total losses due to operational risk occurred as a result of employee errors (https://www.bain.com/insights/how-banks-can-manageoperational-risk/). The issue of operational risk is mostly regulated by the Basel standard, but it has been put in the highlight of academic literature after the financial crisis. These researches have been directed to the general or a statistical perspective (see Cheng, et al. 2007; Jarrow, 2008; Chapelle et al. 2008; Hatzakis, et al. 2010). Parallel to this, literature analysing different aspects of operational risk started to develop, including the influence of operational risk on human resources (Boudreau, et al. 2003; Xu, et al. 2016; Xu, et al. 2017). According to data from Serbia, after 2 years of implementing Basel II, the $54 \%$ of all events occurred as a result of human error. The causes of most mistakes are overwork and fatigue of employees (Knežević, 2013: 48-49).

In order to determine the level of operational risk, we used the data regarding capital requirements for operational risk based on the reports of National Bank of Serbia. Capital requirements for operational risk depend on the approach banks use to calculate this indicator. In Serbian banking sector based on the reports of commercial banks, vast majority of banks (80\%) use Basic indicators approach, while five banks apply Standardized approach in determining the minimum capital requirements for operational risk. As we can see from the Table 3, capital requirements for operational risk are growing in the analysed period with the increase of $16 \%$ from 2011 up to 2019. On the other hand, the share of capital requirements for operational risk in total capital requirement has grown since 2011, reaching its maximum in 2019. Although, we do not have firm data and cannot claim with certainty that the increase in capital requirements for operational risk came as a consequence of the introduction of innovations, 
it is likely that it played a significant role. It is reasonable to expect further increase in operational risk especially if we take into account the trends in the banking sector regarding the introduction of artificial intelligence in business activities, which will certainly affect employees and contribute to their changed role in the new circumstances.

Table 3. Capital requirements for operational risk (bn dinars) during the period $2011-2019$

\begin{tabular}{cc}
\hline Year & Capital requirements for operational risk (bn dinars) \\
\hline 2011 & 22.7 \\
\hline 2012 & 23.45 \\
\hline 2013 & 24.05 \\
\hline 2014 & 24.71 \\
\hline 2015 & 25.50 \\
\hline 2016 & 25.74 \\
\hline 2017 & 25.22 \\
\hline 2018 & 25.81 \\
\hline 2019 & 26.31 \\
\hline
\end{tabular}

Source: National bank of Serbia, Statistical Annex of Banking sector, Fourth Quarter of 2011, 2012, 2013, 2014, 2015, 2016, 2017, $2018,2019$.

Although we could not find precise information in the bank reports and other documents about the amounts of capital requirements for operational risk related to new innovative products, there is a trend of increasing amounts of capital requirements, having in mind that by 2017 the largest number of banks had finished introducing e-banking and $\mathrm{m}$-banking and after that they began to implement new products and services in their operations to a greater extent. We can claim to a certain extent that the innovations have contributed to the increase of system and third-party risk (as a part of operational risk), given that banks in cooperation with the software companies participate in the creation of new products and services.

\section{NEW ROLES OF EMPLOYEES IN OPERATIONAL RISK MANAGEMENT}

Despite the fact that the banking sector experienced growth (in respect to total assets, loans, deposits and other banking items), the number of employees in the sector has been decreasing. The number of employees fell by more than 6,000 during the analysed period. This reduction is partially due to structural changes in the banking sector, such as mergers and acquisitions, reducing the number of branches and cutting costs, but one of the reasons also include the introduction of innovation and digitalization as claimed by BIS (BIS, 2018).

Table 4. Number of employees in Serbian banking sector during the period 2011-2019

\begin{tabular}{lrrrrrrrrr}
\hline & 2011 & 2012 & 2013 & 2014 & 2015 & 2016 & 2017 & 2018 & 2019 \\
\hline $\begin{array}{l}\text { Number } \\
\text { of em- } \\
\text { ployees }\end{array}$ & 29,228 & 28,394 & 26,380 & 25,106 & 24,257 & 23,847 & 23,055 & 22,830 & 23,087 \\
\hline
\end{tabular}

Source: National bank of Serbia, Statistical Annex of Banking sector, Fourth Quarter of 2011, 2012, 2013, 2014, 2015, 2016, $2017,2018,2019$.

No matter structural changes in the Serbian banking sector, the introduction of innovation, higher level of capital requirements for operational risk and fewer employees can indicate two things. Either the new technologies caused by digitalization are replacing the employees or employees face higher workload and pressure that contributes to the creation of tension among employees and increase the frequency of their mistakes. In the management of employees and clients, the effects of workload and stress on employees could entail severe operational risks (Xu et al., 2017). We have tried to determine what was the dominant cause of the decrease in the number of employees and what were the units mostly affected by this downsizing. Unfortunately, we did not manage to obtain the data on changes of the number of employees in the banking sector of Serbia according to the units they are employed in. We leave the possibility that there was an increase in the number of employees in the risk department, 
including the stuff dealing with operational risk. However, having in mind that activities of all employees are one of the sources of operational risk, downsizing puts an additional pressure, especially to those dealing directly with new products and services.

The bank's productivity and profitability, beside technology and capital, mostly depend on quality of work employees are performing. On the other hand, the success in operational risk management is directly related to performance of employees, given that operational risks are related to behaviour of all employees in the bank. According to the Operational Risk Function Survey 2018 Operational Risk professionals identified the ability to influence people as one of the most required capabilities, followed by the technical acumen and product knowledge, while skills associated with the traditional risk measurement technics, such as research and quantitative skills and risk stress testing were classified as currently least useful (UK Finance, 2018). Also, due to increasing exposure to operational risk as a result of the introduction of new products, as well as the threat of system failure and greater dependence on third parties outsourced by the bank, it is necessary to employ experts in the operational risk department.

\section{CONCLUSION}

The banking sector has been facing a number of changes in recent years, including the introduction of innovations in their operations. Banks are adapting to the new environment, strengthening the market position, increasing the opportunities for acquiring new and retaining existing clients, as well as achieving cost savings and operational efficiency.

The results of this research indicate increased level of innovation, a higher degree of operational risk, but also a decrease in the number of employees. Although numerous studies and regulators indicate that the introduction of innovations increase operational risk, we have not been able to find firm evidence of this relationship and based on the analysis and review of research we have only been able to draw general conclusions. Introduction of new products and services can cause negative experience for employees dealing with them. They might face operational risks of which they are not aware, did not receive explicit demand to identify or monitor these events, or there is a fear about reporting a personal mistake. With the constant innovations and evolution of the workplace in banking sector, employees need to be able to adapt to fast changes and adapt new skills needed to preform new work tasks. Although, investment in their training is recognized as one of the major solutions, it is not always implemented and employees in this case need to have the ability to learn from experiences and to apply that learning to new and different situations. Banks that are leaders in introduction of innovation have already identified these issues and have put behavioural culture in relation to exposure to operational risks as one of the priority goals.

\section{ACKNOWLEDGEMENTS}

This paper is supported by the Ministry of Science and Technological Development of the Republic of Serbia.

\section{LITERATURE}

Basel Committee on Banking Supervision. (2018). Sound Practices: Implications of fintech developments for banks and bank supervisor. Retrieved from https://www.bis.org/bcbs/ publ/d431.pdf. Accessed on September 12, 2020.

Boudreau J., Hopp W., McClain J., L. \& Thomas J. (2003). On the Interface Between Operations and Human Resources Management. Manufacturing \& Service Operations Management, 5(3), 179-202.

Chapelle, A., Crama, Y., Hübner, G., \& Peters, J. P. (2008). Practical methods for measuring and managing operational risk in the financial sector: A clinical study. Journal of Banking \& Finance, 32(6), 1049-1061.

Cheng, F., Gamarnik, D., Jengte, N., Min, W., \& Ramachandran, B. (2007). Modeling operational risks in business processes. Journal of Operational Risk, 2(2), 73-98.

Decision on Risk Management by Banks RS Official Gazette, Nos 45/2011, 94/2011, 119/2012, 123/2012, 23/2013 - other decision, 43/2013, 92/2013, 33/2015, 61/2015, 61/2016, 103/2016, 119/2017, 76/2018, 57/2019, 88/2019 and 27/202.

Đukić Đ. (2016). Upravljanje rizicima i kapitalom u bankama. Beograd: Centar za izdavačku delatnost Ekonomskog fakulteta.

Ekpu, V. (2015). Measuring and Reporting Financial Innovation Performance and its Impact: A Review of Methodologies. West African Institute for Financial and Economic Management (WAIFEM). Dubai: UAE.

EY (2016). Leading through innovation, The future of banking in emerging markets. Retrieved from https://www. ey.com/Publication/vwLUAssets/ey-leading-throughinnovation-the-future-of-banking-in-emergingmarkets/\%24File/ey-leading-through-innovation-thefuture-of-banking-in-emerging-markets.pdf. Accessed on September 7, 2020.

EY (2018). Global banking outlook 2018, Pivoting toward an innovation-led strategy. Retrieved from https://www. ey.com/Publication/vwLUAssets/ey-global-bankingoutlook-2018/\$File/ey-global-banking-outlook-2018. pdf. Accessed on September 7, 2020.

EY (2020). Banking in the new decade, Tree big bets to boost profitability and free up capital to invest in transformation. Retrieved from https://www.ey.com/en_gl/banking-new-decade. Accessed on September 7, 2020. 
Frame, W. S., \& White, L. J. (2004). Empirical studies of financial innovation: lots of talk, little action? Journal of economic literature, 42(1), 116-144.

Hatzakis, E. D., Nair, S. K., \& Pinedo, M. (2010). Operations in financial Services-An overview. Production and Operations Management, 19(6), 633-664.

Jarrow, R. A. (2008). Operational risk. Journal of Banking \& Finance, 32(5), 870-879.

Knežević, M. (2013). Operational risk-challenges for banking industry. Economic analysis, 46(1-2), 40-52.

Korenik, D. (2019). The concept of sustainable innovation as applied to banking intermediation. Prace Naukowe Uniwersytetu Ekonomicznego we Wrocławiu, 63(5), 63-77.

KPMG (2015). Next Generation Banking Survey. Retrieved from https://assets.kpmg/content/dam/kpmg/ pdf/2015/10/Next-Generation-Banking-Survey.pdf. Accessed on September 3, 2020.

KPMG (2020). The future is open, Reshaping the banking experience 2019 trends in review. Retrieved from https:// assets.kpmg/content/dam/kpmg/xx/pdf/2020/01/thefuture-is-open.pdf. Accessed on September 3, 2020.

National bank of Serbia, Statistical Annex of Banking sector, Fourth Quarter of 2011, 2012, 2013, 2014, 2015, 2016, 2017, 2018, 2019.
Neufeind M., O'Reilly J., \& Ranft F. (2018). Work in the digital age: Challenges of the fourth industrial revolution. Rowman \& Littlefield International Ltd , pp. 309. Retrieved from https://policynetwork.org/wp-content/uploads/2018/06/ Work-in-the-Digital-Age.pdf. Accessed on September 3,2020 .

OECD (2005). Oslo Manual. Guidelines for Collecting and Interpreting Innovation Data, Eurostat.

UK Finance, the Institute of Operational Risk and RiskBusiness (2018). Operational Risk Function Survey 2018. Retrieved from https://www.ior-institute.org/wp-content/ uploads/2019/05/Operational-Risk-Function-Survey_ FINAL_01.04.2019150871.pdf. Accessed on September 10, 2020.

Xu, Y., Zhu, L., \& Pinedo, M. (2016). Operational risk management: Coordinating capital investment and firm value. Working paper, NYU.

Xu, Y., Pinedo, M., \& Xue, M. (2017). Operational risk in financial services: A review and new research opportunities. Production and Operations Management, 26(3), 426-445.

https://www.bain.com/insights/how-banks-can-manage-operational-risk/. Accessed on September 14, 2020.

https://nbs.rs/sr_RS/drugi-nivo-navigacije/statistika/. Accessed on September 23, 2020. 